\title{
Fast protocol for high frequency in vitro cloning of Banana (Musa acuminata) cv. Grande Naine
}

\author{
S. R. Parida ${ }^{1}$, S. Beura ${ }^{2}$, S. Rout ${ }^{3 *}$, R. Beura ${ }^{4}$ and P. N. Jagadev ${ }^{5}$ \\ ${ }^{1}$ Department of Biotechnology, GITAM University, Visakhapatnam- 530045 (Andhra Pradesh), INDIA \\ ${ }^{2}$ Biotechnology-cum-Tissue Culture Centre, Orissa University of Agriculture and Technology, Bhubaneswar- \\ 751003 (Odisha), INDIA \\ ${ }^{3}$ School of Forestry and Environment, Sam Higginbottom Institute of Agriculture Technology \& Sciences, \\ Allahabad-211007 (Uttar Pradesh), INDIA \\ ${ }^{4}$ College of Basic Science and Humanity, Orissa University of Agriculture and Technology, Bhubaneswar-751003 \\ (Odisha), INDIA \\ ${ }^{5}$ Dean of Research, Orissa University of Agriculture and Technology, Bhubaneswar-751003 (Odisha), INDIA \\ *Corresponding author. E-mail:srout.forestry@gmail.com
}

Received: April 29, 2016; Revised received: September 26, 2016; Accepted: January 9, 2017

\begin{abstract}
An investigation was conducted on Fast Protocol for High Frequency in vitro cloning of Banana (Musa acuminata) cv. Grande Naine at the Biotechnology-cum-Tissue Culture Center, OUAT, Bhubaneswar, during the year 2012. This has helped to determine the best media compositions for shoot multiplication and rooting of $\mathrm{cv}$. Grande Naine, so as to get optimum results with a minimized cost of production. MS medium supplemented with 4.0 $\mathrm{mg} / 1$ Benzylaminopurine (BAP) and $2.0 \mathrm{mg} / 1$ Kinetin gave the highest number of shoot/explants (11.33) in 30 days. However, MS medium when supplemented with $6.0 \mathrm{mg} / 1$ BAP produced a maximum number of leaves (19.07) with a maximum height $2.73 \mathrm{~cm}$. Among various concentrations of indole-3-acetic acid (IAA), indole-3-butyric acid (IBA) and naphthaleneacetic acid (NAA) for rooting. Half MS medium supplemented with $1.0 \mathrm{mg} / 1 \mathrm{IBA}$ was found to be ideal for early rooting and producing more number of roots in 21 days. However, MS basal medium was found to be the best treatment to support the formation of long roots. This protocol can be very useful to the future research worker and as well as entrepreneurs for mass production of banana (Musa acuminata) cv. Grande Naine.
\end{abstract}

Keywords: In vitro, inoculation, Musa acuminate, Shoot proliferation

\section{INTRODUCTION}

Banana is the common name for herbaceous plants of the genus Musa. They are native to tropical South and Southeast Asia, and are likely to have been first domesticated in Papua New Guinea (Lentfer and Boyd, 2007). Today, they are cultivated throughout the tropics. They are grown in at least 107 countries, (FAO, 2005) primarily for their fruit, and to a lesser extent to make fiber, banana wine and as ornamental plants. India is the world's largest producer of Banana with 13.90 million tonnes followed by Uganda (10.14 million tonnes) (Sahoo et al., 2015). Almost all modern edible parthenocarpic bananas come from two wild species -Musa acuminata and Musa balbisiana. Grande Naine bananas (also spelled Grand Nain) are banana cultivars of Musa acuminata. 'Grande Naine' or 'Grand Nain' literally translates from French meaning "Large Dwarf" (Randy, 2007). Unfortunately, expansion of banana production is frequently limited by costly high quality planting materials. The farmer produced suckers are good transmitters of insect pests and dis- eases (Rahman et al., 2004; Haq and Dahot, 2007). This has prompted interest in the use of in vitro tissue culture technique. Micro propagation of banana is highly efficient, allowing a large turnover of plants in a very short period of time within very little space (Arias, 1992; Arvanitoyannis et al., 2007). Tissue culture technology offers many other advantages besides being pest and disease free. Compared to conventional planting material, tissue culture plants give higher yield and earlier more vigorous sucker production. Tissue culture plants are uniform, allow for mass production in relatively short periods of time, and are available all year round which are important criteria for commercial farming. Rapid and easy mass production also allows for facilitated distribution of improved cultivars, and can compensate for planting material shortages. This high value crop var. Grande Naine is propagated vegetatively through mother rhizome and suckers. The rate of multiplication is very slow as a plant produces only 4-5 suckers in a year. The underground structures are exposed to natural disasters, pests and pathogens and thus the risk of 
spreading infection is more. Besides, higher cost of rhizome production and tedious method of transporting a high volume of planting material are constraints faced by the grower (Sahoo et al., 2015). Considering the problems associated with this important crop, it is essential to find out an alternative of propagation for by passing the slow rate of multiplication, reduce the cost of transportation and bulking up true to type disease free stocks of high yielding new cultivars within a shorter period. Therefore, the present investigation was carried out in the banana (Musa acuminata) cv. Grande Naine, with the objective to find out the impact of BAP, kinetin, IAA, IBA and NAA plant bioregulators on shoot proliferation and standardization of media supplements for root formation.

\section{MATERIALS AND METHODS}

The present investigation was carried out at Biotechnology-cum-Commercial Tissue Culture Center, OUAT, Bhubaneswar.

Source of explants: For this study, Healthy and disease free plants of Musa acuminata cv. Grande Naine were maintained in the farm of Biotechnology-cumCommercial Tissue Culture Center, OUAT, Bhubaneswar, as mother plant block for conducting in vitro research and commercial plantlet production in the laboratory. The explants for this experiment were taken from a pre-established multiple shoot Culture of var. Grande Naine.

Stock solution, media preparation and sterilization: The chemicals used for the present study were analytical reagents of excel $\mathrm{R}$ grade of Titan Biotech Ltd., Ranbaxy Laboratory Ltd., Merck (India), Qualigen Fine Chemicals, and Himedia Laboratories Ltd. (India). Auxins, Cytokinins, myo-inositol and Fe-EDTA were supplied by Sigma (USA) and Agar from Ranbaxy Laboratory Limited. MS Medium (Murashige and Skoog, 1962) was used throughout the investigation, required quantities of macronutrients, micronutrients, Fe-EDTA, vitamins and plant bioregulators were taken from the stock solution and required quantity of sucrose dissolved in distilled water was added fresh to the medium. The $\mathrm{pH}$ of the solution was adjusted to $5.7 \pm 0.1$ using $0.1 \mathrm{~N} \mathrm{NaOH}$ or $0.1 \mathrm{~N} \mathrm{HCL}$. Then volume was made up to $1 \mathrm{~L}$ with distilled water. Agar $(0.6 \% \mathrm{w} / \mathrm{v})$ was added to the medium boiled and poured into the culture bottles and capped. Culture bottles containing culture medium were autoclaved for the 20 minutes at $121^{\circ} \mathrm{C}$ and $15 \mathrm{Psi}$ pressure. The autoclaved medium was kept in a laminar air flow bench for cooling. All the glassware were dipped in the detergent solution for overnight and washed under running tap water. They were rinsed with distilled water and then dried in an oven for $2 \mathrm{hrs}$ at $150^{\circ} \mathrm{C}$. Forceps, Petridis and scalpel were thoroughly cleaned with isopropanol or rapped with paper and kept in a clean sterilized in autoclave at $15 \mathrm{psi}$ and $121^{\circ} \mathrm{C}$ for 20 minutes. The working chamber of laminar air flow cabinet was wiped with isopropanol. Filtered air (80-100 cft/min) to ensure that particles do not settle in working area was blown for 5 minutes. The sterilized materials to be used (except living tissue) were kept in the chamber and exposed to UV light for 30 minutes.

Inoculation: The explants (preferably with 1-2 shoots) were carefully inoculated to the MS medium containing different concentration of cytokinins BAP (4.0, 5.0, 6.0 and $7.0 \mathrm{mg} / \mathrm{l})$ in combination with Kinetin $(2.0 \mathrm{mg} / \mathrm{l})$ and in combination with IAA $(1.0 \mathrm{mg} / \mathrm{l})$ for shooting as per the treatments. Three replications per treatment and 3 culture bottles per replication were marked for observation of 17 different treatments. Observations on the number of shoots per explants, shoot length, number of leaves were recorded from 10 DAI (Days after inoculation). Subsequent observations were noted at $20 \mathrm{DAI}$ and $30 \mathrm{DAI}$. Upon attaining a desired height in the shoot multiplication medium (preferably $4-5 \mathrm{~cm}$ from the media level), the plantlets were then carefully transferred to half MS and MS medium containing different concentrations of auxins (IAA, IBA and NAA) 1.0 and 2.0. $\mathrm{mg} / \mathrm{l}$ Three replications per treatment and 2 culture bottles per replication were marked for observation of 14 different treatments. Observations on the number of roots per explants and root length were recorded from 7 DAI (Days after Inoculation). Subsequent observations were noted at 14 DAI and 21 DAI.

Establishment of culture: After inoculation, the culture were kept at $25 \pm 2^{0} \mathrm{C}$ in an air conditioned room with a 16 hours light period (3000-3200 lux) supplied by fluorescent tubes and $80 \%$ relatively humidity (Al- amin et al., 2009).

Statistical analysis: The raw data obtained during the experimental observations were subjected to statistical analysis as per method by Gomez and Gomez, (1984). The significance and non- significance of the treatment effect were judged with the help of ' $F$ ' variance ratio test. Calculated ' $F$ ' value was compared with the table value of ' $\mathrm{F}$ ' at $5 \%$ level of significance. The data were transferred from where ever required before suitability of Analysis of Variance (ANOVA) analyzed in statistical package SAS version 7.0.

\section{RESULTS AND DISCUSSION}

During the present course of investigation from the data presented in table 1 for the shoot proliferation study of cultivar Grand Naine revealed that after 10 days of inoculation, MS medium fortified with BAP $(6.0 \mathrm{mg} / 1)$ significantly enhanced the height of the plant $(1.78 \mathrm{~cm})$ and stood at par with the treatments $\mathrm{T}_{9}$ $\left(\mathrm{MS}+7.0 \mathrm{mg} / 1 \mathrm{BAP}+2.0 \mathrm{mg} / 1\right.$ Kinetin), $\mathrm{T}_{3}(\mathrm{MS}+$ $5.0 \mathrm{mg} / 1 \mathrm{BAP})$ and $\mathrm{T}_{8}(\mathrm{MS}+6.0 \mathrm{mg} / 1 \mathrm{BAP}+2.0$ $\mathrm{mg} / 1$ Kinetin). Significantly maximum number of leaves (9.27) was recorded in treatment $\mathrm{T}_{4}(\mathrm{MS}+6.0$ $\mathrm{mg} / 1 \mathrm{BAP})$. MS medium fortified with BAP $(5.0 \mathrm{mg} / 1$ 
S. R. Parida et al. / J. Appl. \& Nat. Sci. 9 (1): 72 - 79 (2017)

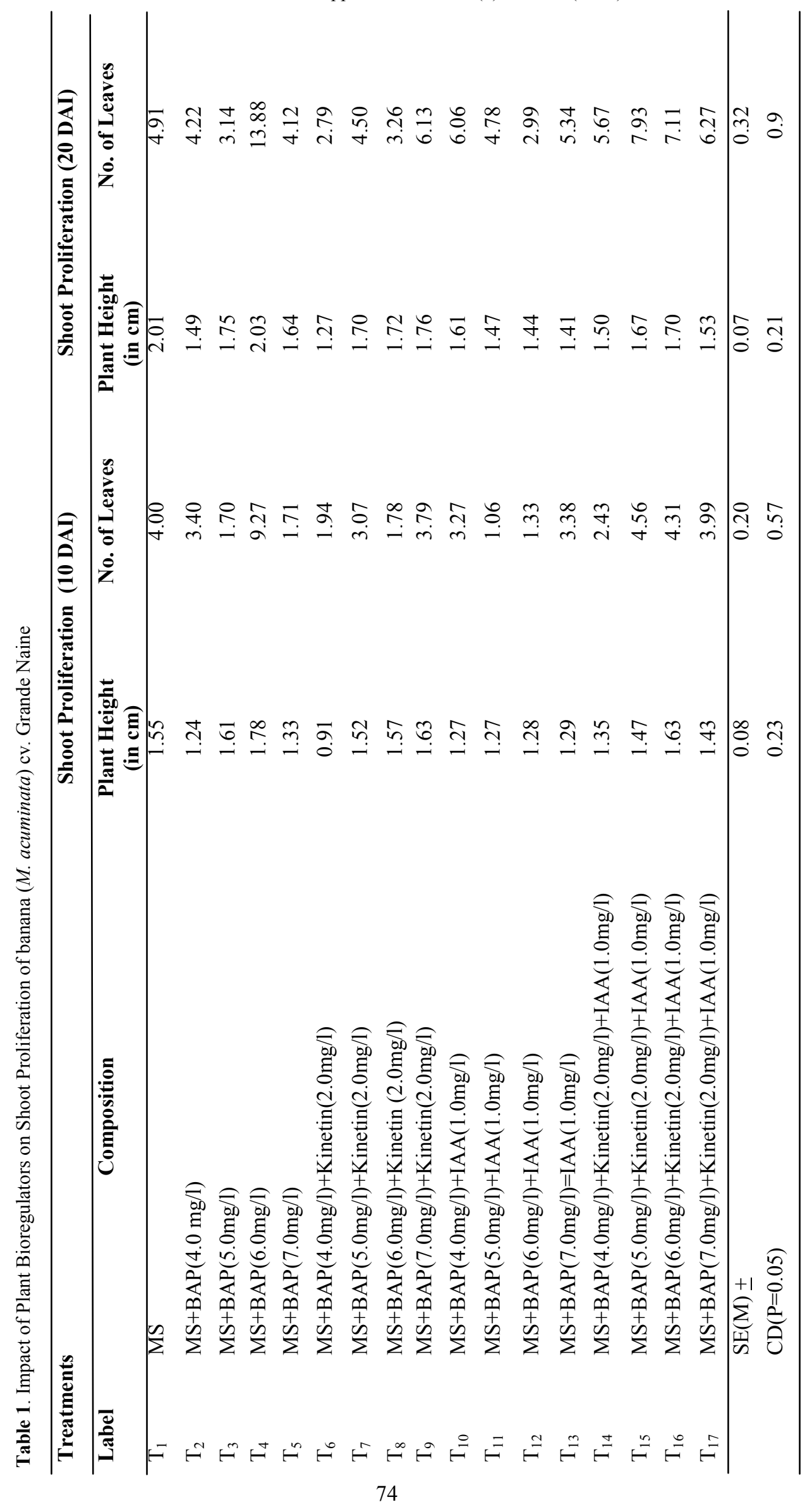


S. R. Parida et al. / J. Appl. \& Nat. Sci. 9 (1): 72 - 79 (2017)

Table 2. Impact of Plant Bioregulators on Shoot Proliferation of Banana (M. acuminata) cv. Grande Naine (30DAI).

\begin{tabular}{|c|c|c|c|c|}
\hline \multicolumn{2}{|r|}{ Treatments } & \multirow{2}{*}{$\begin{array}{l}\text { No. of shoots/ } \\
\text { plant }\end{array}$} & \multirow{2}{*}{$\begin{array}{l}\text { Plant height } \\
\quad \text { (in cm) }\end{array}$} & \multirow{2}{*}{$\begin{array}{c}\text { No. of leaves / } \\
\text { plant }\end{array}$} \\
\hline Label & Composition & & & \\
\hline $\mathrm{T}_{1}$ & MS & 6.21 & 2.56 & 10.25 \\
\hline $\mathrm{T}_{2}$ & $\mathrm{MS}+\mathrm{BAP}(4.0 \mathrm{mg} / \mathrm{l})$ & 9.05 & 1.77 & 7.36 \\
\hline $\mathrm{T}_{3}$ & $\mathrm{MS}+\mathrm{BAP}(5.0 \mathrm{mg} / \mathrm{l})$ & 9.15 & 2.02 & 8.06 \\
\hline $\mathrm{T}_{4}$ & $\mathrm{MS}+\mathrm{BAP}(6.0 \mathrm{mg} / \mathrm{l})$ & 9.26 & 2.73 & 19.07 \\
\hline $\mathrm{T}_{5}$ & $\mathrm{MS}+\mathrm{BAP}(7.0 \mathrm{mg} / \mathrm{l})$ & 5.52 & 2.63 & 9.83 \\
\hline $\mathrm{T}_{6}$ & $\mathrm{MS}+\mathrm{BAP}(4.0 \mathrm{mg} / \mathrm{l})+\mathrm{Kinetin}(2.0 \mathrm{mg} / \mathrm{l})$ & 11.33 & 1.89 & 4.62 \\
\hline $\mathrm{T}_{7}$ & $\mathrm{MS}+\mathrm{BAP}(5.0 \mathrm{mg} / \mathrm{l})+\mathrm{Kinetin}(2.0 \mathrm{mg} / \mathrm{l})$ & 8.99 & 1.89 & 10.05 \\
\hline $\mathrm{T}_{8}$ & $\mathrm{MS}+\mathrm{BAP}(6.0 \mathrm{mg} / \mathrm{l})+\mathrm{Kinetin}(2.0 \mathrm{mg} / \mathrm{l})$ & 6.28 & 1.87 & 7.30 \\
\hline $\mathrm{T}_{9}$ & $\mathrm{MS}+\mathrm{BAP}(7.0 \mathrm{mg} / \mathrm{l})+\mathrm{Kinetin}(2.0 \mathrm{mg} / \mathrm{l})$ & 6.17 & 1.84 & 10.33 \\
\hline $\mathrm{T}_{10}$ & $\mathrm{MS}+\mathrm{BAP}(4.0 \mathrm{mg} / \mathrm{l})+\mathrm{IAA}(1.0 \mathrm{mg} / \mathrm{l})$ & 6.18 & 2.05 & 8.08 \\
\hline $\mathrm{T}_{11}$ & $\mathrm{MS}+\mathrm{BAP}(5.0 \mathrm{mg} / \mathrm{l})+\mathrm{IAA}(1.0 \mathrm{mg} / \mathrm{l})$ & 6.33 & 1.58 & 7.36 \\
\hline $\mathrm{T}_{12}$ & $\mathrm{MS}+\mathrm{BAP}(6.0 \mathrm{mg} / \mathrm{l})+\mathrm{IAA}(1.0 \mathrm{mg} / \mathrm{l})$ & 5.82 & 1.51 & 6.03 \\
\hline $\mathrm{T}_{13}$ & $\mathrm{MS}+\mathrm{BAP}(7.0 \mathrm{mg} / \mathrm{l})+\mathrm{IAA}(1.0 \mathrm{mg} / \mathrm{l})$ & 5.34 & 1.47 & 7.00 \\
\hline $\mathrm{T}_{14}$ & $\mathrm{MS}+\mathrm{BAP}(4.0 \mathrm{mg} / \mathrm{l})+\mathrm{Kinetin}(2.0 \mathrm{mg} / \mathrm{l})+\mathrm{IAA}(1.0 \mathrm{mg} / \mathrm{l})$ & 5.45 & 1.58 & 6.89 \\
\hline $\mathrm{T}_{15}$ & $\mathrm{MS}+\mathrm{BAP}(5.0 \mathrm{mg} / \mathrm{l})+\mathrm{Kinetin}(2.0 \mathrm{mg} / \mathrm{l})+\mathrm{IAA}(1.0 \mathrm{mg} / \mathrm{l})$ & 5.64 & 1.76 & 14.22 \\
\hline $\mathrm{T}_{16}$ & $\mathrm{MS}+\mathrm{BAP}(6.0 \mathrm{mg} / \mathrm{l})+\mathrm{Kinetin}(2.0 \mathrm{mg} / \mathrm{l})+\mathrm{IAA}(1.0 \mathrm{mg} / \mathrm{l})$ & 5.31 & 1.88 & 11.56 \\
\hline \multirow[t]{3}{*}{$\mathrm{T}_{17}$} & $\mathrm{MS}+\mathrm{BAP}(7.0 \mathrm{mg} / \mathrm{l})+\mathrm{Kinetin}(2.0 \mathrm{mg} / \mathrm{l})+\mathrm{IAA}(1.0 \mathrm{mg} / \mathrm{l})$ & 5.21 & 1.65 & 8.83 \\
\hline & $\mathrm{SE}(\mathrm{M}) \pm$ & 0.16 & 0.09 & 0.49 \\
\hline & $\mathrm{CD}(\mathrm{P}=0.05)$ & 0.46 & 0.26 & 1.40 \\
\hline
\end{tabular}

or $6.0 \mathrm{mg} / 1)$ with IAA $(1 \mathrm{mg} / 1)$ reduced the number of leaves per plant. However, the treatment $\mathrm{T}_{1}$ (MS medium only) recorded a mediocre number of leaves per plant. On 20th DAI (Days after Inoculation), the treatment $\mathrm{T}_{4}(\mathrm{MS}+6.0 \mathrm{mg} / 1 \mathrm{BAP})$ significantly enhanced height of plant $(2.03 \mathrm{~cm})$ and the result stood at par with the treatment $\mathrm{T}_{1}$ (MS medium only). Significantly maximum number of leaves per plant (13.88) was observed in the treatment $\mathrm{T}_{4}(\mathrm{MS}+6.0$ mg/1 BAP).

From the perusal of the data presented in table 2, it was evident that the treatment $\mathrm{T}_{6}$ (MS $+4.0 \mathrm{mg} / 1 \mathrm{BAP}+$ $2.0 \mathrm{mg} / 1 \mathrm{Kinetin)}$ significantly increased the number of multiple shoots per explants (11.33). The treatment $\mathrm{T}_{17}(\mathrm{MS}+7.0 \mathrm{mg} / 1 \mathrm{BAP}+2.0 \mathrm{mg} / 1$ Kinetin +1.0 $\mathrm{mg} / 1$ IAA) reduced the number of multiple shoots per plant (5.21). A mediocre number of shoots (9.26) was recorded in treatment $\mathrm{T}_{4}(\mathrm{MS}+6.0 \mathrm{mg} / 1 \mathrm{BAP})$, after 30 days of inoculation. The plant height was significantly higher $(2.73 \mathrm{~cm})$ with $\mathrm{T}_{4}(\mathrm{MS}+6.0 \mathrm{mg} / 1 \mathrm{BAP})$ which stood at par with $\mathrm{T}_{5}(\mathrm{MS}+7.0 \mathrm{mg} / 1 \mathrm{BAP})$ and $\mathrm{T}_{1}(\mathrm{MS}$ medium only). Significantly maximum number of leaves (19.07) per plant was recorded under the treatment $\mathrm{T}_{4}(\mathrm{MS}+6.0 \mathrm{mg} / 1 \mathrm{BAP})$. Considering all the above mentioned characters for shoot proliferation of cultivar Grand Naine after 30 days, it has been concluded that treatment $\mathrm{T}_{6}(\mathrm{MS}+4.0 \mathrm{mg} / 1 \mathrm{BAP}+$ $2.0 \mathrm{mg} / 1$ Kinetin) was found to be best for the production of multiple shoots (11.33) per explant, and the treatment $\mathrm{T}_{4}(\mathrm{MS}+6.0 \mathrm{mg} / 1 \mathrm{BAP})$ was most ideal for production of longer shoots with more number of leaves. During initial stages of growth, i.e., after 10 and 20 days of inoculation, MS medium fortified with BAP at mediocre concentration enhanced the plant height as well as leaf number. Lower concentration of BAP affected the plant height in a decreasing manner. The addition of lower concentration of Kinetin to the BAP fortified medium produced mediocre height plants. However, the combinations of BAP and kinetin failed to produce longer plants with more number of leaves during later stages of growth. After 30 days of inoculation, both plant height and number of leaves were maximum with the inclusion of BAP in MS medium. The combination produced a mediocre number of multiple shoots per explants. However, MS medium fortified with mediocre concentration of BAP and lower concentration of kinetin had shown spectacular effect on the production of multiple shoots per explant. Both BAP and kinetin are considered to be most potent cytokines and played a vital role for production of multiple shoots per explants in table type of banana cv. Grande Naine. Higher concentration of BAP with a lower concentration of kinetin affected the production of multiple shoots per explant, in a decreasing manner. The ability of cytokinin to promote the growth of dicotyledons has been reported by Murashige (1974). Application of cytokinin to the lateral buds promotes the differentiation of vascular traces (Moore, 1989). The effect of cytokinins on breaking the dormancy of axillary buds under in vitro conditions 
S. R. Parida et al. / J. Appl. \& Nat. Sci. 9 (1): 72 - 79 (2017)

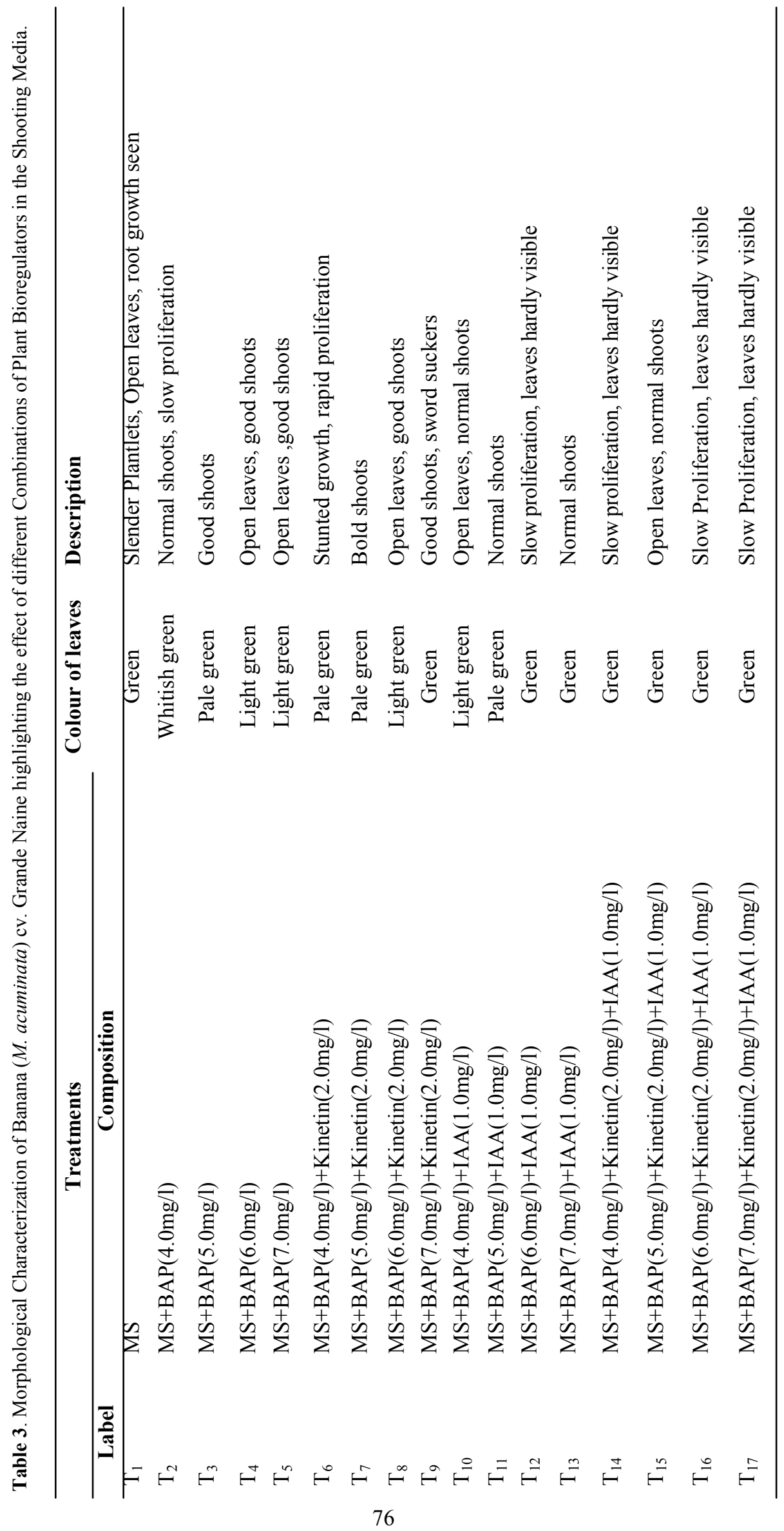


Table 4. Impact of Plant Bioregulators on Root development of Banana (M. acuminata) cv.Grande Naine.

\begin{tabular}{|c|c|c|c|c|c|}
\hline \multicolumn{2}{|r|}{ Treatments } & \multirow{2}{*}{$\begin{array}{l}\text { Number of } \\
\text { Roots / Plant } \\
\text { (7DAI) }\end{array}$} & \multirow{2}{*}{$\begin{array}{l}\text { Number of } \\
\text { Roots/Plant } \\
\text { (14DAI) }\end{array}$} & \multirow{2}{*}{$\begin{array}{c}\text { Number of } \\
\text { Roots/Plant } \\
\text { (21DAI) }\end{array}$} & \multirow{2}{*}{$\begin{array}{c}\text { Root Length } \\
\text { (in cm) } \\
\text { (21DAI) }\end{array}$} \\
\hline Label & Composition & & & & \\
\hline $\mathrm{T}_{1}$ & $1 / 2 \mathrm{MS}$ & 0.83 & 3.70 & 5.00 & 3.39 \\
\hline $\mathrm{T}_{2}$ & $1 / 2 \mathrm{MS}+\mathrm{IAA}(1.0 \mathrm{mg} / \mathrm{l})$ & 0.95 & 4.29 & 6.48 & 1.68 \\
\hline $\mathrm{T}_{3}$ & $1 / 2 \mathrm{MS}+\mathrm{IBA}(1.0 \mathrm{mg} / \mathrm{l})$ & 1.24 & 5.71 & 6.83 & 2.90 \\
\hline $\mathrm{T}_{4}$ & $1 / 2 \mathrm{MS}+\mathrm{NAA}(1.0 \mathrm{mg} / \mathrm{l})$ & 1.41 & 5.29 & 6.58 & 3.02 \\
\hline $\mathrm{T}_{5}$ & $1 / 2 \mathrm{MS}+\mathrm{IAA}(2.0 \mathrm{mg} / \mathrm{l})$ & 0.84 & 4.43 & 6.73 & 2.07 \\
\hline $\mathrm{T}_{6}$ & $1 / 2 \mathrm{MS}+\mathrm{IBA}(2.0 \mathrm{mg} / \mathrm{l})$ & 1.21 & 4.04 & 6.65 & 2.61 \\
\hline $\mathrm{T}_{7}$ & $1 / 2 \mathrm{MS}+\mathrm{NAA}(2.0 \mathrm{mg} / \mathrm{l})$ & 1.37 & 3.99 & 5.37 & 3.12 \\
\hline $\mathrm{T}_{8}$ & MS & 1.10 & 4.13 & 4.64 & 5.29 \\
\hline $\mathrm{T}_{9}$ & $\mathrm{MS}+\mathrm{IAA}(1.0 \mathrm{mg} / \mathrm{l})$ & 1.00 & 3.69 & 4.90 & 3.54 \\
\hline $\mathrm{T}_{10}$ & $\mathrm{MS}+\mathrm{IBA}(1.0 \mathrm{mg} / \mathrm{l})$ & 0.83 & 3.88 & 5.13 & 3.29 \\
\hline $\mathrm{T}_{11}$ & $\mathrm{MS}+\mathrm{NAA}(1.0 \mathrm{mg} / 1)$ & 0.66 & 4.21 & 5.50 & 2.78 \\
\hline $\mathrm{T}_{12}$ & $\mathrm{MS}+\mathrm{IAA}(2.0 \mathrm{mg} / \mathrm{l})$ & 0.52 & 1.89 & 3.08 & 1.87 \\
\hline $\mathrm{T}_{13}$ & $\mathrm{MS}+\mathrm{IBA}(2.0 \mathrm{mg} / \mathrm{l})$ & 0.70 & 2.00 & 3.50 & 3.67 \\
\hline $\mathrm{T}_{14}$ & $\mathrm{MS}+\mathrm{NAA}(2.0 \mathrm{mg} / \mathrm{l})$ & 0.96 & 2.41 & 3.62 & 2.77 \\
\hline & $\overline{\mathrm{SE}(\mathrm{M}) \pm}$ & 0.09 & 0.25 & 0.28 & 0.16 \\
\hline & $\mathrm{CD}(\mathrm{P}=0.05)$ & 0.25 & 0.70 & 0.78 & 0.46 \\
\hline
\end{tabular}

and proliferation of axillary shoots has been reported in various bulbous plants like Iris, Hyacinth, Lilium and Narcissus (Hussey, 1975). Cytokinin at moderate concentrations enhances shoot development: at higher levels it promotes multiple shoots through precocious axillary shoot formation (Ammirato, 1982). Hussain (1995) reported that BAP at higher concentration produced a maximum number of shoots. BAP was reported to be in general the most effective cytokinin for meristem, shoot tip and axillary bud culture of various species (Wang and $\mathrm{Hu}, 1980$; Palai et al., 1997).

It was evident from the data presented in the table 4 that significantly maximum number of roots (1.41) was recorded in $\mathrm{T}_{4}(1 / 2 \mathrm{MS}+1.0 \mathrm{mg} / \mathrm{I} \mathrm{NAA})$, which stood at par with $\mathrm{T}_{3}(1 / 2 \mathrm{MS}+1.0 \mathrm{mg} / 1 \mathrm{IBA}), \mathrm{T}_{7}(1 / 2$ $\mathrm{MS}+2.0 \mathrm{mg} / 1 \mathrm{NAA})$ and $\mathrm{T}_{6}(1 / 2 \mathrm{MS}+2.0 \mathrm{mg} / 1$ IBA), after 7 days of inoculation. The treatment $T_{3}(1 / 2$ $\mathrm{MS}+1.0 \mathrm{mg} / 1 \mathrm{IBA})$ increased the number of roots per plant (5.71) and stood at par with the treatment $T_{4}(1 / 2$ $\mathrm{MS}+1.0 \mathrm{mg} / 1 \mathrm{NAA})$, after 14 days of inoculation. The treatment $\mathrm{T}_{3}(1 / 2 \mathrm{MS}+1.0 \mathrm{mg} / 1 \mathrm{IBA})$ recorded significantly maximum number of roots/plant (6.83) and stood at par with the treatments $\mathrm{T}_{5}(1 / 2 \mathrm{MS}+2.0$ $\mathrm{mg} / 1 \mathrm{NAA}) . \mathrm{T}_{6}(1 / 2 \mathrm{MS}+2.0 \mathrm{mg} / \mathrm{l} \mathrm{IBA}), \mathrm{T}_{4}(1 / 2 \mathrm{MS}$ $+1.0 \mathrm{mg} / 1 \mathrm{NAA})$ and $\mathrm{T}_{2}(1 / 4 \mathrm{MS}+1.0 \mathrm{mg} / 1 \mathrm{IAA})$, after 21 days of inoculation. However, the treatment $T_{8}$ (MS medium only) recorded significantly longer roots $(5.29 \mathrm{~cm})$ in comparison to other treatments. The treatment $\mathrm{T}_{3}(1 / 2 \mathrm{MS}+1.0 \mathrm{mg} / 1 \mathrm{IBA})$ produced more number of roots with mediocre length $(2.90 \mathrm{~cm})$. Considering all above mentioned characters for root formation study, it has been concluded that treatment $\mathrm{T}_{3}(1 / 2 \mathrm{MS}+1.0 \mathrm{mg} / \mathrm{I}$ IBA $)$ produced more number of roots (6.83) per / plant, and the plants attended deep green luxuriant growth. The treatment $\mathrm{T}_{8}$ (MS medium only) was suitable for the production of longer roots. During initial stages of growth (7 days), 1/2 MS medium supplemented with lower concentration of NAA initiated more number of roots per plant. However, in the later stages of root development, an inclusion of IBA at lower concentration in $1 / 2 \mathrm{MS}$ medium had shown a tremendous effect on production of roots. Doubling of the media and plant bioregulators reduced the number of roots per plant throughout the investigation period. MS medium only increased the root length, but they are slender in quality. The addition of auxins had a great role for production of good quality root. The present investigations revealed that auxins (IBA and NAA) help in better rooting of micro shoots (Rout et al., 1995 and Palai et al., 1997). Hussain (1995) reported that lower levels of auxin (0.5 or $1.0 \mathrm{mg} / \mathrm{l} \mathrm{NAA}$ ) induced early rooting. The result obtained in this investigation was in agreement with Tiwari (1997-98), who stated that 1/2 MS medium supplemented with IBA successfully produced roots. MS medium supplemented with NAA developed healthy roots (Meenakshi et al., 2001) in turmeric. Treatments with auxins stimulate and show an increase in peroxidase activity, as was observed by Palai 
S. R. Parida et al. / J. Appl. \& Nat. Sci. 9 (1): 72 - 79 (2017)

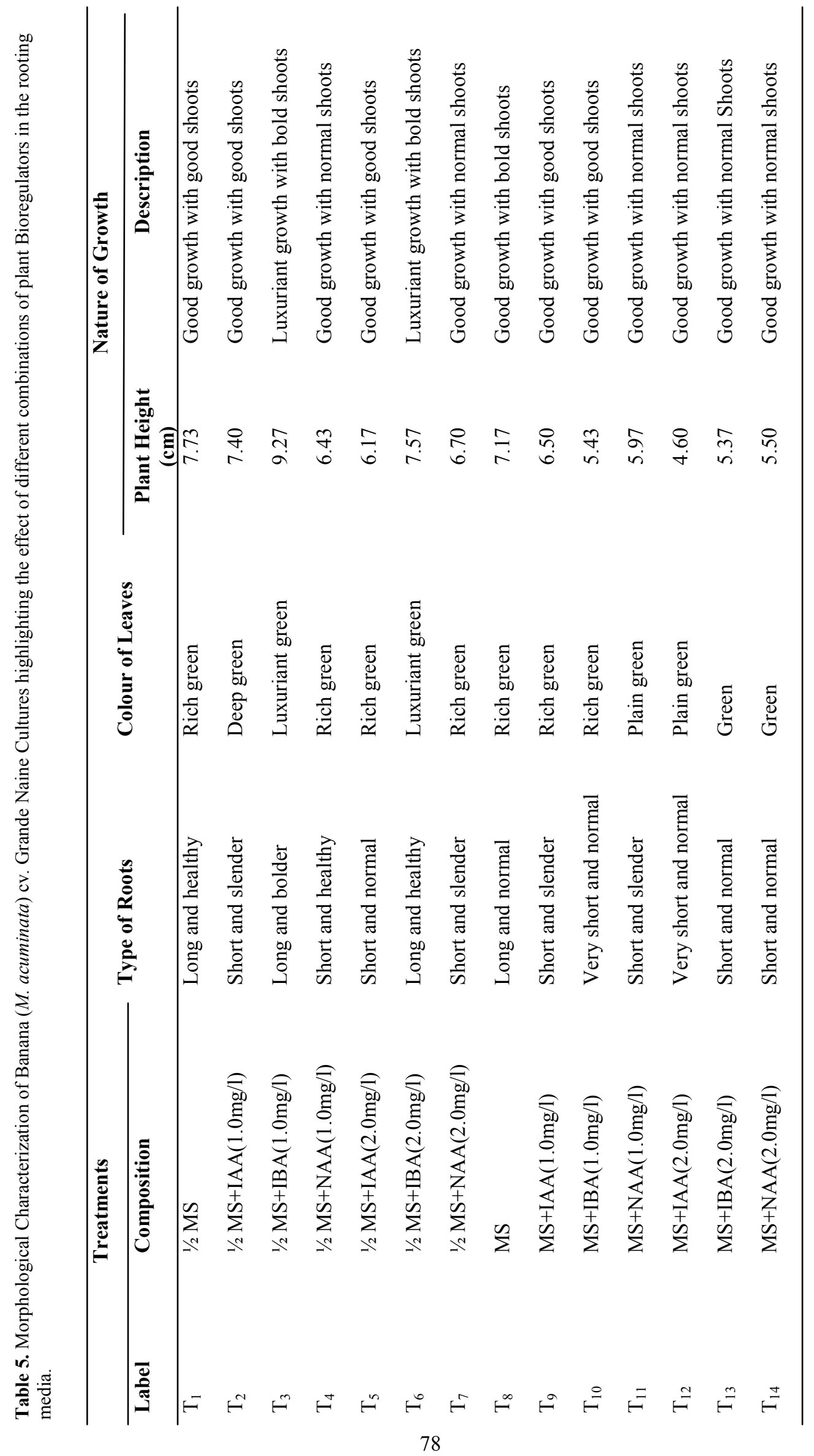


(2001). It may be due to that the auxin entered through the cut surfaces of the proliferated shoots and rapidly absorbed in the cell walls by $\mathrm{pH}$ trapping (Rubery and Sheldrake, 1973). The root induction was gradually decreased with increasing the concentration of auxin type. The different levels of auxin were statistically significant for root induction (Viehmannova et al., 2007). This confirmed the importance of plant bioregulators on the shooting, rooting and on the whole plantlet regeneration.

\section{Conclusion}

The present study concluded that treatment $\mathrm{T}_{6}(\mathrm{MS}+$ $4.0 \mathrm{mg} / 1 \mathrm{BAP}+2.0 \mathrm{mg} / 1 \mathrm{Kinetin}$ ) was found to be best for high frequency multiple shoot proliferation, and the treatment $\mathrm{T}_{4}(\mathrm{MS}+6.0 \mathrm{mg} / 1 \mathrm{BAP})$ was most ideal for the production of longer shoots with more number of leaves. In rooting media, treatment $T_{3}(1 / 2$ $\mathrm{MS}+1.0 \mathrm{mg} / \mathrm{I} \mathrm{IBA}$ ) produced more number of roots (6.83) per plant, and the plants attended deep green luxuriant growth. The treatment $\mathrm{T}_{8}$ (MS medium only) was concluded to be suitable for the production of longer roots. The study thus revealed vital information related to rapid in vitro propagation of banana var. Grande Naine, which can be very useful for mass production of banana (Musa acuminata) cv. Grande Naine by various commercial entrepreneurs.

\section{REFERENCES}

Al-amin, M., Karim, M., Amim, M., Rahaman, S. and Mamun, A.N.M.(2009). In vitro micropropagation of banana (Musa spp.). Bangladesh Jour. Agri. Res. 34 (4):645-659

Ammirato PV (1982). Growth and morphogenesis in cultures of the monocot yam, Dioscorea. In: Plant Tissue Culture, Fugiwara A (Ed.), Maruzen,Tokyo, Japan, pp. 169- 170

Arias, O. (1992). Commercial micropropagation of banana. In: Biotechnology Applications for Banana and Plantain Improvement. Inibap, San Jose, Costa Rica. pp. 139-142

Arvanitoyannis, I.S., Mavromatis, A.G., GrammatikakiAvgeli, O. and Sakellariou, M. (2007). Banana: Cultivars, biotechnological approaches and genetic transformation. Int. Jour. of Food Science and Technology. 43:18711879

FAO. (2005). ProdSTAT: Crops. Food and Agriculture Organization. United Nations. :9-12.

Gomez, K.A. and Gomez, A.A .(1984). Completely Randomized Design. In: Statistical procedures for Agricultural Research, $2^{\text {nd }} E d n$. John Wiley and Sons, New York, 8-20

Haq, I. and Dahot, M.U. (2007). Micropropagation efficiency in banana (Musa sp.) under different immersion systems. Pakistan Journal of Biological Sciences. 10(5):726-733

Hussain, C.T.S. (1995). Response of gladiolus to rapid cloning through in vitro techniques. M.Sc thesis Kerala
Agric, Univ., vellanikkara, Thrissur.

Hussey G. (1975). Totipotency in tissue explant and callus of some members of Liliaceae, Iridaceae and amaryllidaceae. J. Exp. Bot., 26 (91): 253-262

Lentfer, C. and Boyd, W. (2007). "Tracing antiquity of banana cultivation in Papua New Guinea". The Australia \& Pacific Science Foundation. A project undertaken at the Centre for Geoarchaeology and Palaeoenvironmental Research, School of Environmental Science and Management, Southern Cross University, Lismore, NSW.

Meenakshi, N., Sulikeri, G.S., Krishnamoorthy, V. and Hegde, R.V. (2001). Standardization of chemical environment for multiple shoot induction of turmeric (Curcuma longa L.) for in vitro clonal propagation. Crop Research Hisar. 22(3), 449-453

Moore, T.C. (1989). Auxins. In: Biochemistry and Physiology of Plant Hormones. 2nd edn, 28- 93. Nurosa Publ. House. N. Delhi.

Murashige, T. (1974). Plant propagation through tissue culture. Annual Review of Plant Physiology. 25:135-166.

Murashige, T. and Skoog, F. (1962). A revised medium for rapid growth and bioassays with tobacco cultures. Physiologia Plantarum. 15(3):473-497

Palai, S.K. (2001). Studies on physiological, biochemical and molecular status in vitro culture of ginger (Zingiber Officinale Rosc) and turmeric (Curcuma longa L.) Ph.D thesis, Utkal University.

Palai, S.K., Rout, G.R., Das, P. and Edison, S. (1997). Micropropagation of ginger. Interaction of growth regulator and culture condition. Proceedings of the National Seminar on Biotechnology of Spices and Aromatic Plants. (Eds. Raman KV, Sasikumar B, Babu KN, Eapen SJ) Calicut, pp. 20

Rahman, M.Z., Nasiruddin, K.M., Amin, M.A. and Islam, M.N. (2004). In vitro response and shoot multiplication of Banana with BAP and NAA. Asian Journal of Plant Sciences. 3(4): 406-409

Randy, C.P. (2007). Banana and plantain - an overview with emphasis on pacific island cultivars species profiles for pacific island agro forestry ver, 1

Rout, G.R., Palai, S.K., Samantaray, S. and Das, P. (1995). Metabolic changes during in vitro multiplication of Curcuma longa cv. Surama and PTS-28. Acta Botanica Hungarica. 39(3-4): 383-392

Rubery, P.H. and Sheldrake, A.R. (1973). Effect of $\mathrm{pH}$ and surface charge on cell uptake of auxin.Natures (Lond.). New Biol. 244:285-288

Sahoo, C., Beura, S., Rout, S. and Beura. R.(2015). High frequency In vitro cloning of Banana (Musa acuminate) cv. Grande Naine. Int. Jour. of Agri., Environment and Biotechnology. 8(4):943-950

Tiwari. R.S. (1998). Micropropagation of turmeric (Curcuma longa L.). Recent horticulture. 4:145-148

Viehmannova, I., Fernandez, C.E., Hnilicka, F. and Robles, C.D. (2007). The influence of growth regulators on root induction In vitro of Musa genus. Agri. Tropica et Subtropica. 40 (3):115-119

Wang and $\mathrm{Hu}$. (1980). In vitro clonal propagation of ginger sprouts. Acta Botanica Yannanica. 11, 231-233 